\title{
STUDY OF PHYSICOCHEMICAL PROPERTIES AND NUTRIENT CONTENT OF AGRICULTURAL SOILS OF CHITTOOR DISTRICT USING DIFFERENT ANALYTICAL METHODS
}

\author{
SHAKIR BASHA S*, ARUN CHOWDARY V, KIRTHI A \\ Department of Pharmaceutical Analysis, Sree Vidyanikethan College of Pharmacy, Tirupathi - 517 102, Andhra Pradesh, India. \\ Email: shakirbasha72@gmail.com
}

Received: 08 February 2017, Revised and Accepted: 26 March 2018

\section{ABSTRACT}

Objective: The objective of this study is to determine the physicochemical properties and nutrient content of agricultural soils at various stations such as black soil from Kalroad Palli village (Chandragiri mandal), red soil from Ramapuram village (Ramachandrapuram Mandal), and clay from Yerpedu village (Yerpedu Mandal) of Chittoor district.

Method: The physicochemical parameters such as pH was measured using pH meter (Thermo Scientific); electrical conductivity (EC) was measured by conductivity meter (CM180 Elico Technologies); organic carbon (OC) was determined by Fourier-transform infrared (Agilent technologies 630) and with ultraviolet (UV) spectrophotometer (Agilent technologies Cary UV 60); nitrogen (N2) was estimated by Kjeldahl method; potassium (K), sodium $(\mathrm{Na})$, and calcium (Ca) were estimated using flame photometer (Elico Technologies CL/361); and magnesium (Mg) was estimated by titrimetric method.

Results: Among these, pH (black soil - 7.41, red soil - 6.93, and clay - 7.29), EC (black soil - 1.76, red soil - 0.25, and clay - 0.14 microhoms), OC (black soil - $1.22 \%$, red soil - $0.61 \%$, and clay - 0.66\%), $\mathrm{N}_{2}$ (black soil - $0.22 \%$, red soil - $0.25 \%$, and clay - $0.26 \%$ ), K (black soil - 5.7 ppm, red soil - 9.1 ppm, and clay - 8.4 ppm), Na (black soil - 9.5 ppm, red soil - 4.5 ppm, and clay - 5.9 ppm), Ca (black soil - 6.2 ppm, red soil - 5.7 ppm, and clay - 7.8 ppm), Mg (black soil $-0.19 \%$, red soil $-0.25 \%$, and clay $-0.17 \%$ ) ranges were recorded at all the stations.

Conclusion: The present study is a preliminary attempt to study the nature of soils in different agricultural areas in Chittoor district of Andhra Pradesh, India. This could help to understand the nutrient profile of the district and to prescribe the nutrients levels of the crops for their effective growth.

Keywords: Soil, pH, Electrical conductivity, Nutrient content, Organic carbon.

(C) 2018 The Authors. Published by Innovare Academic Sciences Pvt Ltd. This is an open access article under the CC BY license (http://creativecommons. org/licenses/by/4. 0/) DOI: http://dx.doi.org/10.22159/ajpcr.2018.v11i6.21833

\section{INTRODUCTION}

Soil is the complex mixture of water, organic matter, minerals, air, and countless organisms that together support life on the Earth. Soil usually forms the surface of the land. It is the "Skin of the Earth." Soil is capable of supporting the plant life and the nature. Soil has a natural body which is called as "Pedosphere" which has few important functions such as plant growth which means of water storage, supply, and purification $[1,2]$

Usually, soil is defined as the unconsolidated organic or mineral matter on the immediate surface of the earth which serves as a natural medium for the plant growth [3]. If the salinity concentrations of soil increase, there was a reduction in seed germination occurs [4].

Soil is the mixture of inorganic materials (sand, silt, and clay particles), non-living organic matter, and living organisms with the particles arranged into soil structures with space between them which contain air and soil solution. Soil hydro-physical properties are particularly important for crop growth and maintaining soil quality [5]

\section{METHODS}

From the past literature survey, it was come to know that nobody has developed any analytical method for the determination of physicochemical properties and nutrient content of agricultural soils which are present in Chittoor district. Therefore, an attempt was made to determine the physiochemical properties and nutrient content of few agricultural soils of Chittoor district.

\section{Soil samples collection}

Soil samples were collected from various stations such as black soil from Kalroad Palli village (Chandragiri mandal), red soil from Ramapuram village (Ramachandrapuram Mandal), and clay from Yerpedu village (Yerpedu Mandal) of Chittoor district.

\section{Instruments required}

Fourier-transform infrared (FTIR) (Agilent technologies 630), ultraviolet (UV) spectrophotometer (Agilent Technologies Cary UV 60), sonicator (Ultrasonic Sonicator), conductivity meter (CM180 Elico Technologies), flame photometer (Elico Technologies CL/361), pH meter (Thermo Scientific), and microbalance (Sartorius) were used.

\section{Chemicals and reagents}

Ammonium acetate, potassium dichromate, sulfuric acid, boric acid, hydrochloric acid, hydroxylamine hydrochloride, potassium ferric cyanide, triethanolamine, and eriochrome black $\mathrm{T}$ were obtained from Merk Specialties.

\section{Methodology}

Color of soils: By the method of visual evaluation, the color of the soils was identified and shown in Table 1.

\section{pH determination}

$20 \mathrm{~g}$ of $2.0 \mathrm{~mm}$ air-dried soil sample was weighed and transferred into a beaker. $50 \mathrm{ml}$ of distilled water was added, stirred with a glass rod thoroughly for about $5 \mathrm{~min}$, and kept aside for $1 / 2 \mathrm{~h}$. Then, the $\mathrm{pH}$ was measured by keeping the soil samples under the $\mathrm{pH}$ meter [6], and the results are shown in Table 2. 
Electrical conductivity (EC)

The same sample solutions which were prepared for measuring the $\mathrm{pH}$ were used for measurement of EC by allowing the soil water suspension in the beaker to settle down the soil for additional $1 / 2 \mathrm{~h}$. Recorded the EC of sample solutions in ds.m-1 using CM [7,8], and the results are shown in Table 3.

Estimation of sodium, potassium, and calcium in flame photometer using calibration curve method

Preparation of standard stock solutions of sodium, potassium, and calcium

Stock solutions of sodium chloride, potassium chloride, and calcium carbonate were prepared which is having a concentration of $1000 \mu \mathrm{g} / \mathrm{ml}$. From these, linear concentrations of 2, 4, 6, 8, and $10 \mu \mathrm{g} / \mathrm{ml}$ were prepared and injected into flame photometer. The percentage flame intensity of standard solutions is shown in Table 4

Preparation of sample solutions for the estimation of sodium, potassium, and calcium

To $5 \mathrm{~g}$ of soil sample, $50 \mathrm{ml}$ of ammonium acetate solution was added and kept for shaking on a reciprocating shaker for $15 \mathrm{~min}$. Then, the resulting solution was filtered and serial dilutions were made, then introduced into flame photometer [9-11]. The percentage flame intensity of samples is shown in Table 5 .

\section{Estimation of magnesium}

2-4 g of soil sample ( $2 \mathrm{~mm}$ sieved) was weighed and transferred into a conical flask. Then, $30 \mathrm{ml}$ of ammonium acetate was added and shaked for $5 \mathrm{~min}$. After shaking, ammonium acetate solution was decanted, and $30 \mathrm{ml}$ of $0.5 \mathrm{~N} \mathrm{HCl}$ was added to each sample solution. Then, the contents were agitated for $5 \mathrm{~min}$ in an upright loosened position, and the solution was filtered through Whatman filter paper grade No. 1. From this, $20 \mathrm{ml}$ of filtrate was collected, then $50 \mathrm{ml}$ of distilled water was added, and 10$15 \mathrm{ml}$ of ammonium chloride-ammonium hydroxide buffer solution, 10 drops each of hydroxylamine hydrochloride, potassium ferric cyanide, triethanolamine, and eriochrome black $\mathrm{T}$ indicator were added. Then, the resultant solution was titrated with standard EDTA till permanent blue color will appear $[12,13]$. The results are shown in Table 6 .

\section{Estimation of nitrogen procedure}

To the $5 \mathrm{~g}$ of soil sample, $0.1 \mathrm{~g}$ of potassium sulfate and $10 \mathrm{ml}$ of concentrated sulfuric acid were added and then heated up to $30 \mathrm{~min}$ at $420^{\circ} \mathrm{C}$ followed by selenium catalyst. The solution was cooled to $50-60^{\circ} \mathrm{C}$, and $50 \mathrm{ml}$ of distilled water was added to the above solution. Then, $50 \mathrm{ml}$ of $35 \%$ sodium hydroxide was added and heated till the volume reaches to $100 \mathrm{ml}$. To this, $25 \mathrm{ml}$ of $4 \%$ boric acid was added and then titrated with $0.1 \mathrm{M}$ hydrochloric acid using methyl orange as indicator $[14,15]$. The results are shown in Table 7

Identification of organic carbon (OC) by FTIR:

A small amount of each soil sample was placed on the IR sample cell $[16,17]$, and the peaks were recorded which are shown in Figs. 1-3 and spectral ranges are given in Table 8.

\section{Estimation of OC by UV-visible spectroscopy \\ Preparation of standard stock solution}

To the $1 \mathrm{~g}$ of sucrose sample, $1000 \mathrm{ml}$ distilled water was added. From that, $10,20,30,40,50,60,70,80,90$, and $100 \mu \mathrm{g} / \mathrm{ml}$ concentration solutions were prepared by adding $10 \mathrm{ml}$ potassium dichromate and $20 \mathrm{ml}$ sulfuric acid in each $100 \mathrm{ml}$ volumetric flask. Then, the absorbances of resulting solutions were checked using UV visible spectrophotometer [18-20], and the results are shown in Table 9.

\section{Preparation of sample solutions}

$1 \mathrm{~g}$ of each soil sample was weighed and transferred into a $100 \mathrm{ml}$ flask. Then, $10 \mathrm{ml}$ potassium dichromate and $20 \mathrm{ml}$ sulfuric acid were added and shaken well and then allowed it to cool on asbestos sheet.
Volume was made up to $100 \mathrm{ml}$ with distilled water and kept for overnight. Then, the absorbance was measured at $660 \mathrm{~nm}$ wavelength on spectrophotometer [5,21], and the results are shown in Table 10.

\section{RESULTS}

\section{DISCUSSION}

The physicochemical properties and nutrient content of selected samples were estimated using different analytical techniques, and the soil
results were found to be as follows.

The $\mathrm{pH}$ of the different soils was black soil - 7.41 (slightly alkaline), clay - 7.29 (slightly alkaline), and red soil - 6.83 (neutral). EC: black soil - 1.76 , clay -0.14 , and red soil -0.25 . The estimation of metal ions such as $\mathrm{Na}, \mathrm{K}$, and Ca was done using flame photometry, and the results were found to be as follows: in black soil, $\mathrm{Na}-9.5 \mu \mathrm{g} / \mathrm{ml}, \mathrm{K}-5.7 \mu \mathrm{g} / \mathrm{ml}$, and Ca - $6.2 \mu \mathrm{g} / \mathrm{ml}$; in Clay, $\mathrm{Na}-5.9 \mu \mathrm{g} / \mathrm{ml}, \mathrm{K}-8.4 \mu \mathrm{g} / \mathrm{ml}$, and $\mathrm{Ca}-7.8 \mu \mathrm{g} / \mathrm{ml}$; in red soil, $\mathrm{Na}-4.5 \mu \mathrm{g} / \mathrm{ml}, \mathrm{K}-9.1 \mu \mathrm{g} / \mathrm{ml}$, and Ca $-5.7 \mu \mathrm{g} / \mathrm{ml}$. The amount of magnesium was estimated using titrimetric analysis, and the results were found to be as follows: For black soil $0.19 \%$, clay $0.17 \%$, and red soil $0.25 \%$. The nitrogen content was estimated using Kjeldahl method and the result was found to be as follows: for black soil $0.22 \%$, clay $0.26 \%$, and red soil $0.25 \%$. The OC was estimated using IR and UV spectrophotometer, and the content of carbon was found to be $1.22 \%$ in black soil, $0.66 \%$ in clay, and $0.61 \%$ in red soil.

\section{CONCLUSION}

The present study is a preliminary attempt to study the nature of soil in different agricultural areas in Chittoor district of Andhra Pradesh, India. This could help to understand the nutrient profile of the district and to prescribe the nutrients levels of the crops for their effective growth.

Table 1: Color of soils

\begin{tabular}{lll}
\hline S.No & Type of soil & Color \\
\hline 1. & Black & Light gray \\
2. & Clay & Light brown \\
3. & Red & Red \\
\hline
\end{tabular}

Table 2: pH of soils

\begin{tabular}{llll}
\hline S.No & Type of soil & pH & Result \\
\hline 1. & Black & 7.41 & Slightly alkaline \\
2. & Clay & 7.29 & Slightly alkaline \\
3. & Red & 6.93 & Neutral \\
\hline
\end{tabular}

Table 3: EC of soils

\begin{tabular}{llll}
\hline S.No & Soil type & EC in $\mathbf{d S . \mathbf { m } ^ { - \mathbf { 1 } }}$ & Result \\
\hline 1. & Black & 1.76 & Poor seed emergence \\
2. & Clay & 0.14 & Good soil \\
3. & Red & 0.25 & Good soil \\
\hline EC: Electrical conductivity & &
\end{tabular}

Table 4: Percentage flame intensity of standard solutions

\begin{tabular}{lllll}
\hline S.No & $\begin{array}{l}\text { Standard solution } \\
(\boldsymbol{\mu} \mathbf{g} / \mathbf{m l})\end{array}$ & $\begin{array}{l}\text { Sodium } \\
(\% \mathbf{F I})\end{array}$ & $\begin{array}{l}\text { Potassium } \\
(\% \mathbf{F I})\end{array}$ & $\begin{array}{l}\text { Calcium } \\
(\% \mathbf{F I})\end{array}$ \\
\hline 1. & 2 & 4.18 & 26.3 & 25.2 \\
2. & 4 & 6.34 & 39.1 & 32.5 \\
3. & 6 & 10.84 & 48.4 & 47.2 \\
4. & 8 & 14.76 & 57.2 & 53.5 \\
5. & 10 & 19.23 & 68.4 & 64.1 \\
\hline
\end{tabular}


Table 5: Percentage flame intensity of soil samples

\begin{tabular}{|c|c|c|c|c|c|c|c|c|c|}
\hline \multirow{2}{*}{$\frac{\text { Metal }}{\text { Sodium }}$} & \multicolumn{3}{|c|}{ Black $(\mathrm{mg} / \mathrm{ml})$} & \multicolumn{3}{|c|}{ Clay (mg/ml) } & \multicolumn{3}{|c|}{$\operatorname{Red}(\mathrm{mg} / \mathrm{ml})$} \\
\hline & 100 & 1 & 0.01 & 100 & 1 & 0.01 & 100 & 1 & 0.01 \\
\hline & 1871 & 184.2 & 18.9 & 1123 & 113.2 & 10.4 & 690.5 & 69.5 & 6.81 \\
\hline Potassium & 4784 & 465.0 & 45.4 & 6012 & 602.9 & 59.1 & 6459 & 642.3 & 63.2 \\
\hline Calcium & 4996 & 489.9 & 48.1 & 5239 & 517.9 & 52.54 & 4787 & 475.2 & 46.2 \\
\hline
\end{tabular}

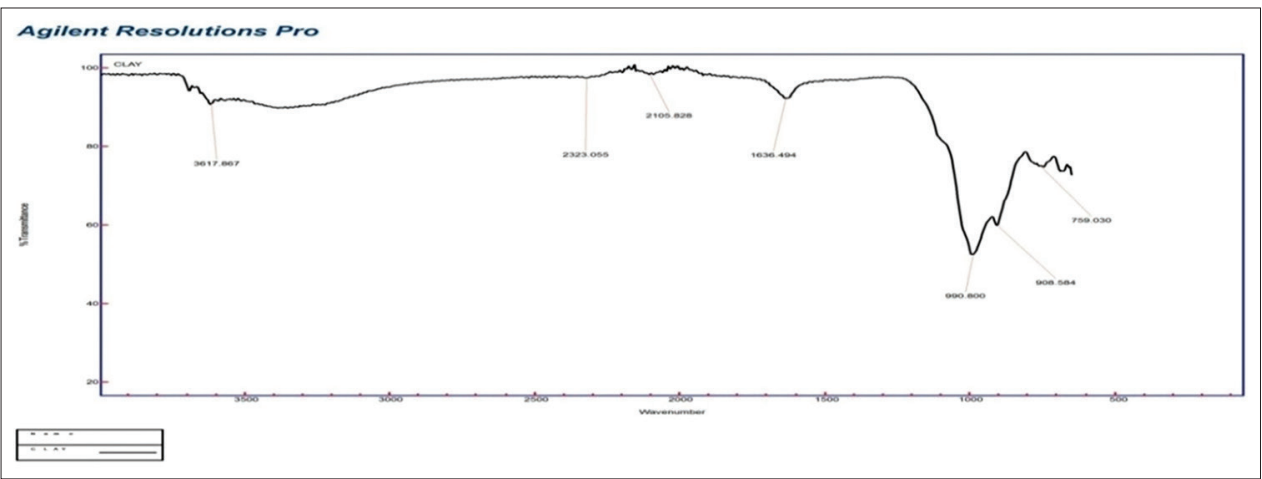

Fig. 1: Infrared spectrum of clay soil

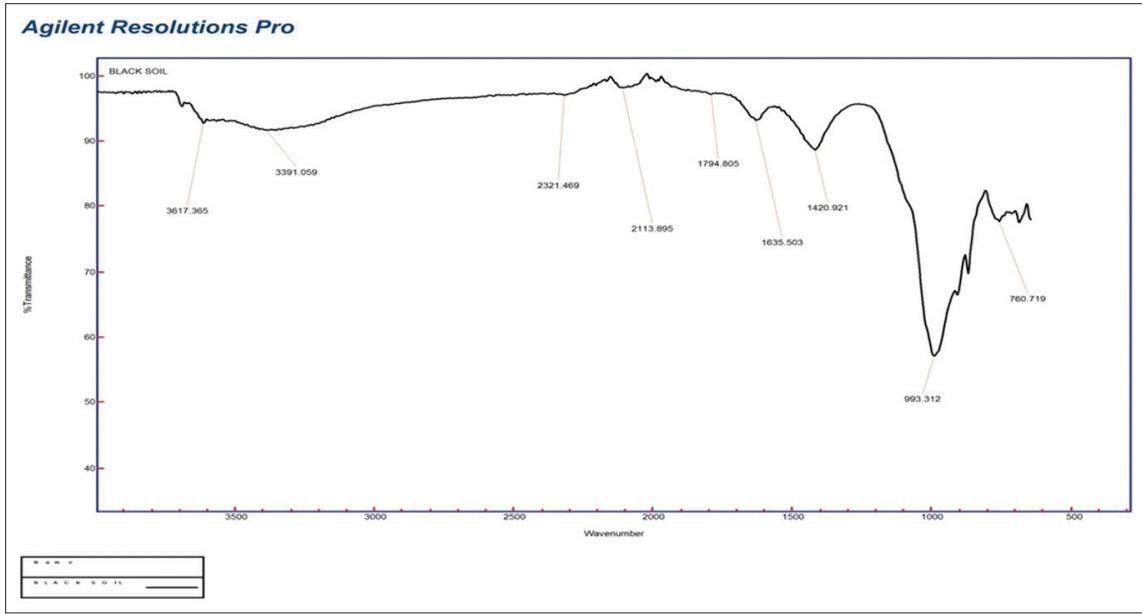

Fig. 2: Infrared spectrum of black soil

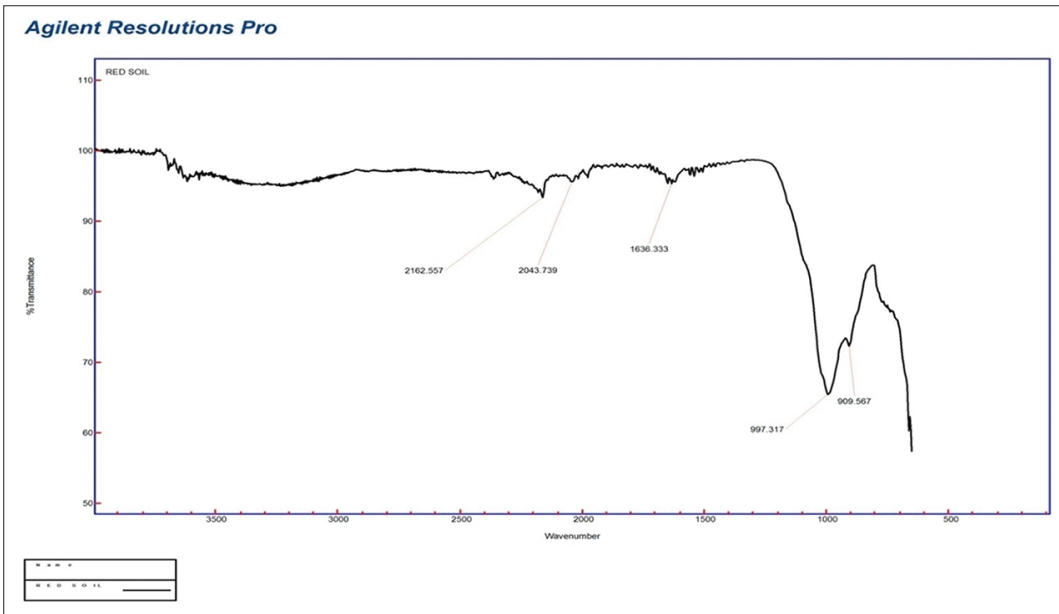

Fig. 3: Infrared spectrum of red soil 
Table 6: Percentage Mg content of soils

\begin{tabular}{lll}
\hline Type of soil & Titrant volume & \% Mg \\
\hline Black & 32 & 0.19 \\
Clay & 28 & 0.17 \\
Red & 37 & 0.24 \\
\hline
\end{tabular}

Table 7: Percentage $\mathrm{N}_{2}$ content of soils

\begin{tabular}{lll}
\hline Type of soil & Titrant volume & $\mathbf{\% ~}_{\mathbf{2}}$ \\
\hline Black & 18 & 0.22 \\
Clay & 21 & 0.26 \\
Red & 20 & 0.25 \\
\hline
\end{tabular}

Table 8: IR spectral ranges of various soils

\begin{tabular}{llll}
\hline \multirow{2}{*}{ Assignment } & \multicolumn{2}{l}{ FTIR region $\mathbf{( \mathbf { c m } ^ { - 1 } )}$} \\
\cline { 2 - 4 } & Black & Clay & Red \\
\hline N-H stretch (Amine) & 3617.365 & 3617.867 & - \\
O-H stretch & 3391.085 & - & - \\
Alkynyl C = C stretching & 2113.895 & 2105.828 & 2043.739 \\
C = C bending & 1635.503 & 1636.494 & 1636.333 \\
C = C stretching & 1420.921 & - & - \\
= C-H bending & 993.312 & 990.800 & 997.317 \\
& 760.719 & 908.584 & 809.567 \\
& & 759.030 & \\
\hline
\end{tabular}

FTIR: Fourier-transform infrared

Table 9: UV absorbance of standard solution

\begin{tabular}{llll}
\hline S.NO & Standard solution $(\boldsymbol{\mu g} / \mathbf{m l})$ & Carbon $\%$ & Absorbance \\
\hline 1. & 10 & 0.04 & 0.0541 \\
2. & 20 & 0.16 & 0.0968 \\
3. & 30 & 0.23 & 0.1521 \\
4. & 40 & 0.31 & 0.3106 \\
5. & 50 & 0.49 & 0.4637 \\
6 & 60 & 0.61 & 0.6281 \\
7. & 70 & 0.69 & 0.6829 \\
8. & 80 & 0.94 & 0.9307 \\
9. & 90 & 1.16 & 1.1470 \\
10. & 100 & 1.33 & 1.2995 \\
\hline
\end{tabular}

Table 10: UV absorbance of soil samples

\begin{tabular}{llll}
\hline S.No & Type of soil & Absorbance & \% Carbon \\
\hline 1. & Black & 1.2595 & 1.22 \\
2. & Clay & 0.6567 & 0.66 \\
3. & Red & 0.6242 & 0.61 \\
\hline
\end{tabular}

UV: Ultraviolet

\section{ACKNOWLEDGMENT}

The author thanks the management and the principal of Sree Vidyanikethan College of Pharmacy for providing the infrastructure and their support to carry out the research work.

\section{FINANCIAL SUPPORT AND SPONSORSHIP}

Nil.

\section{CONFLICTS OF INTEREST}

There are no conflicts of interest.

\section{REFERENCES}

1. Miller A. The Skin of Earth. New Delhi: Indian Agricultural Research Institute; 1953.

2. Chesworth W. Encyclopaedia of Soil Science. Canada: University of Guelph. Springer; 2008.

3. David KA, Bradley ML. Soil Science Course, Soil and Plant Nutrients. NC State Extension: Raleigh; 2016.

4. Pattnaik B, Chaturvedi N, Kar D. Germination and seedling growth of some selected agricultural crops under various a biotic stresses. Int $\mathrm{J}$ Pharm Pharm Sci 2016;8:360-4.

5. Jenifer P, Samuel AS. Study of physicochemical characteristics of agricultural soils of Tuticorin district. Tamil Nadu. Indian Asian J Pharm Tech 2016;6:21-3.

6. Gilluly J, Clement A, Woodford W, Oswald A. Principles of Geology. $4^{\text {th }}$ ed. San Francisco: California; 1975.

7. Schoonver JE, Crim JF. An introduction to soil concepts and the role of Soils. Watershed Manag J Contem Water Res Educ 2015;154:21-47.

8. Mausbach MJ. Soil Quality Considerations in the Conversion of CRP Land to Crop Production; 1996. p. 22-3.

9. Mishra A, Sachan SG, Pandey DM. Maize rhizosphere microbial population in soils of Jharkhand. Int J Pharm Pharm Sci 2015;7:218-22.

10. Determination of Sodium and Potassium by Flame Photometry. Meditsiiniline Keemia/Medical Chemistry. 04.09.12.

11. Wysor WG. Musser "Bobby" Grisso. Soil Electrical Conductivity. Virginia Tech Mark Alley. p. 442-508.

12. University of Canterbury. Determination of Total Calcium and Magnesium Ion Csoncentration. $12^{\text {th }}$ ed. New Zealand: University of Canterbury; 2013. p. 156-9.

13. Vepraskas, et al, Organochlorine insecticide residues in the soils of Romania. Poland: Polish Plant Protection Institute and International $\mathrm{HCH}$ and Pesticides Association; 2001. p. 507-11.

14. Physical Geography Fundamental EBooks. Ch. 10. p. 154-68.

15. Kamble VV, Gaikwad NB. Fouritroer transform infrared specctroscopic studies in Embelia Ribes Burm. A vulnerable medicinal plant. Asian J Pharm Clin Res 2016;9:41-7.

16. Raphael L. Application of FTIR Spectroscopy to Agricultural Soil Analysis. Israel: Israel Institute of technology; 2011.

17. Zhu F, Lu X. The heavy metals and sulphur status of agricultural soils in Poland. In: Soil Quality, Sustainable Agriculture and Environmental Security in Central and Eastern Europe. Netherlands: Kluwer Academic Publishers; 2015. p. 37-47.

18. Parr P. Physical-physico-chemical and chemical properties of soils of newly established agro-biodiversity park of Acharya NG Ranga Agricultural University. Int J Farm Sci 2001;2:102-16.

19. Giller, Feller C, et al. Establishing a benchmark system for monitoring soil quality in Canada. In: Soil Quality for Crop Production and Ecosystem Health. Amsterdam: Elsevier; 2001. p. 323-37.

20. Parkin TB. Soil Monitoring and Soil Information Systems in Germany. Hungary: Research Institute for Soil Science and Agricultural Chemistry of the Hungarian Academy of Sciences; 1996. p. 93-100.

21. Laboratory Testing Procedure for Soil and Water Analysis by Directorate of Irrigation Research and Development (DIRD). Government of Maharashtra Document No. SSD/GL.01. 